\title{
Productivity of sunflower hybrids with erectoid leaves at various plant densities ${ }^{\text {is }}$
}

\author{
Aleksandr S. Bushnev*, Yakov N. Demurin and Gennady I. Orekhov \\ V.S. Pustovoit All-Russian Research Institute of Oil Crops, Krasnodar, Russia
}

Received 22 October 2020 - Accepted 2 July 2021

\begin{abstract}
We carried out the research in 2018-2019 in the Western Ciscaucasia on leached chernozem, low-humus, extra-heavy, heavy-loamy to study the possibility of cultivation of new sunflower genotypes with a compact habitus at a high plant density $(80000,100000$ and 120000 plants/ha) and a row width of $35 \mathrm{~cm}$. We chose sunflower hybrids of the breeding of V.S. Pustovoit All-Russian Research Institute of Oil Crops with the normal (Triumph and Berkut) and the erectoid (Triumph er-2, Triumph Er-3, Berkut er-2, Berkut Er-3) leaf position as an object of research. The high lodging capacity of the erectoid hybrids Triumph er-2 (30.2\%) and Triumph Er-3 (10.9\%) suggests potential yield losses due to non-threshing of heads during the combine harvesting. The highest productivity and oil content of seeds of normal and erectoid hybrids was obtained at the plant density of 80000 plants/ha. The densification of sowings to 100000 and 120000 plants/ha led to a decrease in the traits of yield structure and productivity. The limited resources of the environment do not allow achieving both high productivity and product quality in sowings with the plant density exceeding 80000 plants/ha. The compact habitus of sunflower plants is not a determining factor in the development of productivity of sowings with a high plant density.
\end{abstract}

Keywords: sunflower / erectoid leaf type / plant density / thick planting / cultivation technology

Résumé - Productivité d'hybrides de tournesol à feuilles érigées pour différentes densités de peuplement. Les recherches ont été menées en 2018-2019 en Ciscaucasie Occidentale sur un tchernoziom lessivé, peu humifère, de type «loam» argileux, pour étudier la possibilité de cultiver de nouveaux génotypes de tournesol à architecture compacte conduits à une densité de plantes élevée $(80000,100000$ et 120000 plantes $/$ ha) et avec un inter-rang de $35 \mathrm{~cm}$. Les hybrides de tournesol étaient issus de la sélection du V.S. Pustovoit All-Russian Research Institute of Oil Crops et se différenciaient par un port foliaire étalé (Triumph et Berkut) ou érigé (Triumph er-2, Triumph Er-3, Berkut er-2, Berkut Er-3). La forte sensibilité à la verse des hybrides érigés Triumph Er-2 (30,2\%) et Triumph Er-3 (10,9\%) suggère des pertes de rendement potentielles lors de la moisson du fait du non battage des capitules. Les productivités et teneurs en huile des graines les plus élevées ont été obtenues à la densité de 80000 plantes/ha aussi bien pour les hybrides normaux que érigés. La densification des semis à 100000 et 120000 plantes/ha a conduit à une diminution du rendement et de ses composantes. Les ressources limitées de l'environnement ne permettent pas d'atteindre à la fois une productivité et une qualité des graines élevées pour des densités de plantation dépassant 80000 plantes/ha. Une architecture compacte des plantes de tournesol n'est pas apparue comme un facteur déterminant dans l'accroissement de la productivité en peuplements très denses.

Mots clés : tournesol / feuillage érigé / densité de peuplement / semis très dense / technique de culture

\footnotetext{
is Contribution to the Topical Issue "Sunflower / Tournesol".

*Correspondence: vniimk-agro@mail.ru
} 


\section{Highlights}

The compact habitus of sunflower hybrids is not a determining factor in the development of productivity of sowings with a high plant density on the leached chernozem of the Western Ciscaucasia. The environmental resources allow achieving high productivity in sowings with the plant density of 80000 plants/ha.

\section{Introduction}

In modern conditions of intensification of agricultural production, there is an interest in the application of new cultivation technologies aimed at a more complete use of environmental resources by plants (e.g. light), in particular, in dense planting. In this respect, the development of a compact morphotype of a plant is an important direction in breeding.

In the process of introducing sunflower into cultivation, there was a significant change in its habitus-from branched multi-head wild-growing forms to single-head varieties and hybrids.

There are four identified erectoid genes of sunflower leaves that cause a compact plant habitus. Two of them are dominant - Er (erectoid leaf) and $E r_{3}$ (Fig. 1), two of them are recessive $e r_{1}$ and $e r_{2}$ (Fig. 2). Intergenic interaction is carried out according to the type of dominant epistasis $E r_{3}>E r>e r_{1}$ and $e r_{2}$, as well as recessive epistasis $e r_{2}>e r_{1}$ (Vedmedeva and Tolmachyov, 2001; Demurin and Tolmachyova, 2005; Tolmachyova and Demurin, 2008).

In one of the first work on the study of sunflower lines with a recessive erectoid leaf it was established that the biological yield of seeds is increased by $28 \%$ with densification of sowing from 40000 to 80000 plants/ha (Skaloud and Kovacik, 1992).

On the other hand, the effect of various planting patterns and densities of sunflower on yield was studied. Planting patterns included wide rows, conventional rows, twin rectangular rows and twin zigzag rows. Populations of plants were at 3 levels including 6,8 and 10 plants per square meter. The results show that different planting patterns sometimes produced higher yield, but not always. Furthermore, the equidistant plant placement at the equal plant densities produced a higher radiation interception and extinction coefficient. Moreover, when row width was reduced, grain yield increased. The greatest increase in radiation interception and in the extinction coefficient in response to the planting patterns and plant densities was observed in twin zigzag rows of 8 plants $/ \mathrm{m}^{2}$. Twin zigzag rows of 8 plants $/ \mathrm{m}^{2}$ and conventional rows of 8 plants $/ \mathrm{m}^{2}$ produced the highest yield (Zarea et al., 2005).

Many studies have been dedicated to the problems of sunflower cultivation at the various plant densities (Wahba et al., 1990; Calviño et al., 2004; Echarte et al., 2011; Soleymani, 2017; EL-Satar et al., 2017; López-Pereira et al., 2020). In world practice, there are known methods of sunflower cultivation for commercial and seed purposes with the different row widths (from 45 to $90 \mathrm{~cm}$ ) and plant densities (from 20000 to 90000 plants/ha). To establish an upper limit on the commercially suitable plant density of sunflower, there

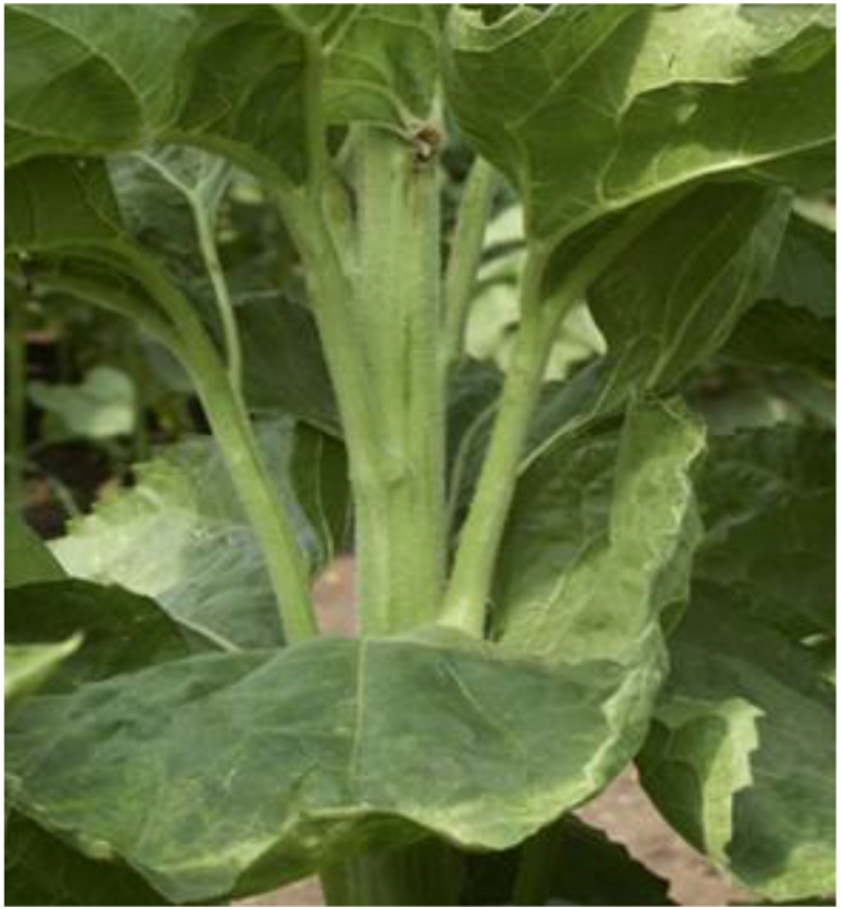

Fig. 1. Dominant Er-3 phenotype of erectoid leave.

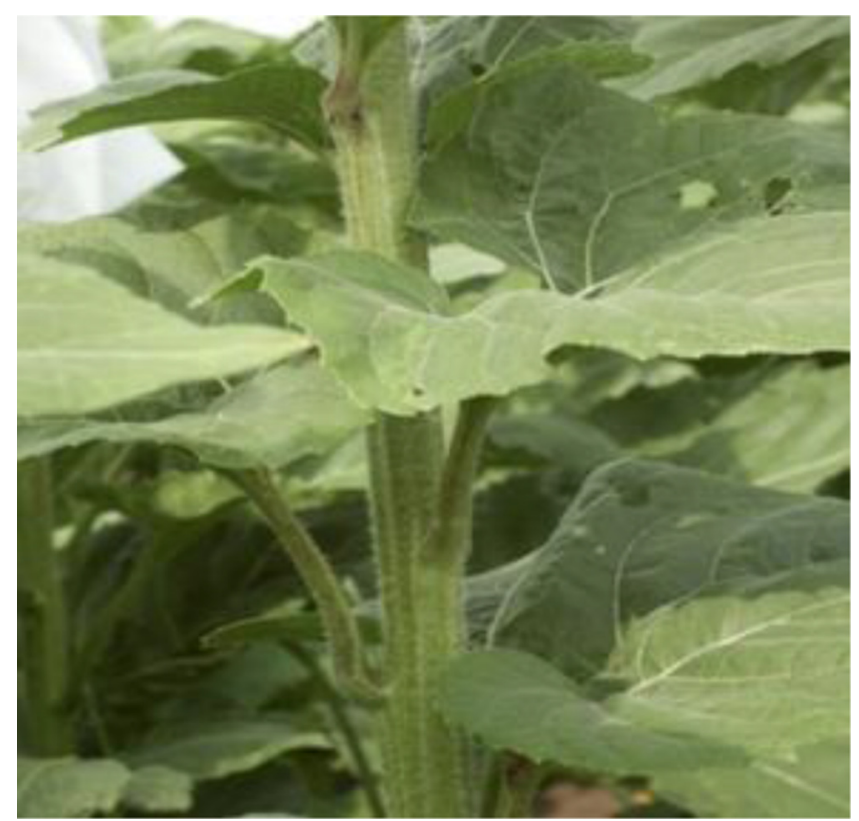

Fig. 2. Recessive er-2 phenotype of erectoid leave.

were studies in Argentina on lodging-resistant hybrids even with the density of $160000 \mathrm{plants} / \mathrm{ha}$ (Hall et al., 2010). The research on identification of the effect of planting density (45000, 60000, 75000, and 90000 plants/ha) on field performance of five sunflower hybrids showed that most of the characteristics of yield and quality largely depend on both the density of sowings and hybrids and factor interaction. 
It was determined that at the lowest plant density, the plant has the smallest height and the highest indicators of leaf area, head diameter, thousand-seed weight, percentage of oil in seeds and unsaturated fatty acids (oleic and linoleic). At the same time, the low density led to a decrease in days to harvesting, leaf area index, dry matter yield, seed yield per hectare, total yield of oil and saturated fatty acids (palmitic and stearic). The hybrid Record exceeded other genotypes in most of the studied yield and quality indicators and showed the highest seed yield $(3.6 \mathrm{t} / \mathrm{ha})$ and total oil yield $(1.23 \mathrm{t} / \mathrm{ha})$ at the density of 75000 plants/ha (Ibrahim, 2012).

In field studies of the effect of a plant density (17000, 35000 , and $46000 \mathrm{plants} / \mathrm{ha}$ ) on sunflower productivity, carried out in the south of Portugal, the highest yield was obtained at an average density of 35000 plants/ha. The decrease in the density to 17000 plants/ha increased the average seed weight, but this was not enough to compensate for the significant decrease in seed weight from the crop acreage (Barros et al., 2004).

For sunflower grown under the irrigation conditions, an increase in the density from 50000 to 150000 plants/ha decreased the number of initiated flowers that gave full seeds from 68 to $38 \%$. With an increase in the plant density, the number of seeds, the weight of one seed, the yield of oil per plant and the yield index decreased (Steer et al., 1986).

One of the conditions for obtaining high productivity of sunflower is its cultivation considering the optimal feeding area. The feeding area means the land area with the corresponding to it volumes of soil and air occupied by one plant. The right choice of the feeding area and, consequently, the plant density, determines the fullness of use of the sunlight energy, water, and soil nutrients for the development of yield and the quality of products. When the plants are densified, they are mutually oppressed, and when the plants are spaced, they do not fully use the given feeding area. In either case, there is a yield shortage, a deterioration in its quality (Vorobiev, 1972).

In Russia, sunflower is mainly sown with row width of $70 \mathrm{~cm}$ (Tab. 1, 1-3) and plant density is differentiated according to the maturity group of a genotype, region, water availability, etc. The main advantage of these technologies is the efficient weed control and improved cultivation conditions through inter-row cultivation.

With this method of sowing, the shape of the feeding area is not regulated and is presented in the form of an elongated quadrangle with a width equal to the row width $(b=70 \mathrm{~cm})$, the length of which depends on the plant density and has several disadvantages due to the uneven distribution of plants in the area. The sunflower root system in such sowings does not use water and nutrients fully enough, the plants use solar energy incompletely, and with an increase in the number of plants in a row, the competition for growth factors increases, which can manifest itself from the initial phases of development and hinder the realization of the productivity potential. As a result, researchers often fail to raise the sunflower yield by increasing the plant density (Ludanova et al., 2015; Vladimirov and Chugunov, 2018; Kurbanov et al., 2018; Lukomets and Tishkov, 2019; Tishkov and Shkarupa, 2020). In addition, this method of sowing does not consider the biological characteristics of individual genotypes, in particular, the height, number and size of leaves, the shape of the leaf blade and the general habitus of plants.
It is obvious that the plants cultivation must be carried out in the conditions when the shape of feeding area of each plant is in the form of a square or a quadrangle close to a square. Similarly, a uniform distribution of plants can be achieved by reducing the row width by half, that is, up to $35 \mathrm{~cm}$, and by cultivating plants at the density of $80000-120000$ plants/ha. (Tab. 1, 4-6). At the same time, there is a reason to believe that a larger number of plants cultivated with a feeding area close to a square can increase the productivity of cenosis, especially in case of using hybrids that are responsive to a uniform feeding area. Thus, in the studies of I. Aksyonov, a decrease in the row width from 70 to $15 \mathrm{~cm}$ with a simultaneous increase in the density from 45000 to 65000 plants/ha allowed increasing the yield of the non-erectoid sunflower hybrid Kharkovskiy 58 by $0.63 \mathrm{t} / \mathrm{ha}$, and the variety Lider - by 0.35 t/ha (Aksyonov, 2007).

The studies carried out in Spain with sunflower cultivation under irrigation conditions at the density of 5000 to 100000 plants/ha have shown that the reactions of biomass, number of seeds and yield depend on the used hybrid (Villalobos et al., 1994). These studies are especially important for new hybrids with a modified habitus, which allows reducing the competition for light due to erectoid leaves. Therefore, we carried out research on the cultivation of sunflower with an erectoid position of leaves at the various plant densities with a row width of $35 \mathrm{~cm}$.

\section{Materials and methods}

We carried out the research in 2018-2019 at the fields of V.S. Pustovoit All-Russian Research Institute of Oil Crops (VNIIMK) (Krasnodar, Russia) in the conditions of the Western Ciscaucasia. The soil of experimental plots is leached chernozem, low-humic, extra-heavy, heavy-loamy, characterized by high natural fertility, high water permeability, hygroscopicity and maximum field water capacity. The depth of humic and transitional horizons is $160-180 \mathrm{~cm}$. The granulometric composition is homogeneous by profile, the amount of clay particles ranges from 64 to $72 \%$, of which $38-42 \%$ are silt particles, there is almost no sand. The soil structure is lumpy-granular. The equilibrial bulk weight of the plowing layer is $1.24-1.29 \mathrm{~g} / \mathrm{cm}^{3}$, increasing in the $\mathrm{C}$ horizon to $1.4-1.6 \mathrm{~g} / \mathrm{cm}^{3}$. The total soil space is $50-53 \%$, the ratio of capillary and non-capillary porosity is $85: 15$. The productive water amount in the two-meter soil horizon is $251-298 \mathrm{~mm}$, or $34-41 \%$ from maximum field water capacity. The wilting moisture in the soil layer of $0-150 \mathrm{~cm}$ ranges from 16 to $17 \%$, in deeper soil layer-from 13 to $15 \%$. This indicates the soil ability to retain a significant amount of water for a long time.

We made the observations, recording and analyzes using established procedures (Lukomets, 2010). The seeds from 540 plants were harvested each year for analysis. We studied sunflower hybrids with an erectoid type of leaves, controlled by two different erectoid genes; these hybrids are analogs of two non-erectoid interlines hybrids Triumph (Fig. 3) and Berkut (Fig. 4) of VNIIMK breeding. We obtained the seeds of the studied hybrids in the laboratory of genetics of VNIIMK, under the code names Triumph er-2 (Fig. 5), Triumph Er-3 (Fig. 6), Berkut er-2 (Fig. 7) and Berkut Er-3 (Fig. 8). In sunflower, erectoid leaf results more to petiole than to leaf blade angle modification. 
Table 1. Sowing variants of sunflower with the various plant densities/plant feeding areas.

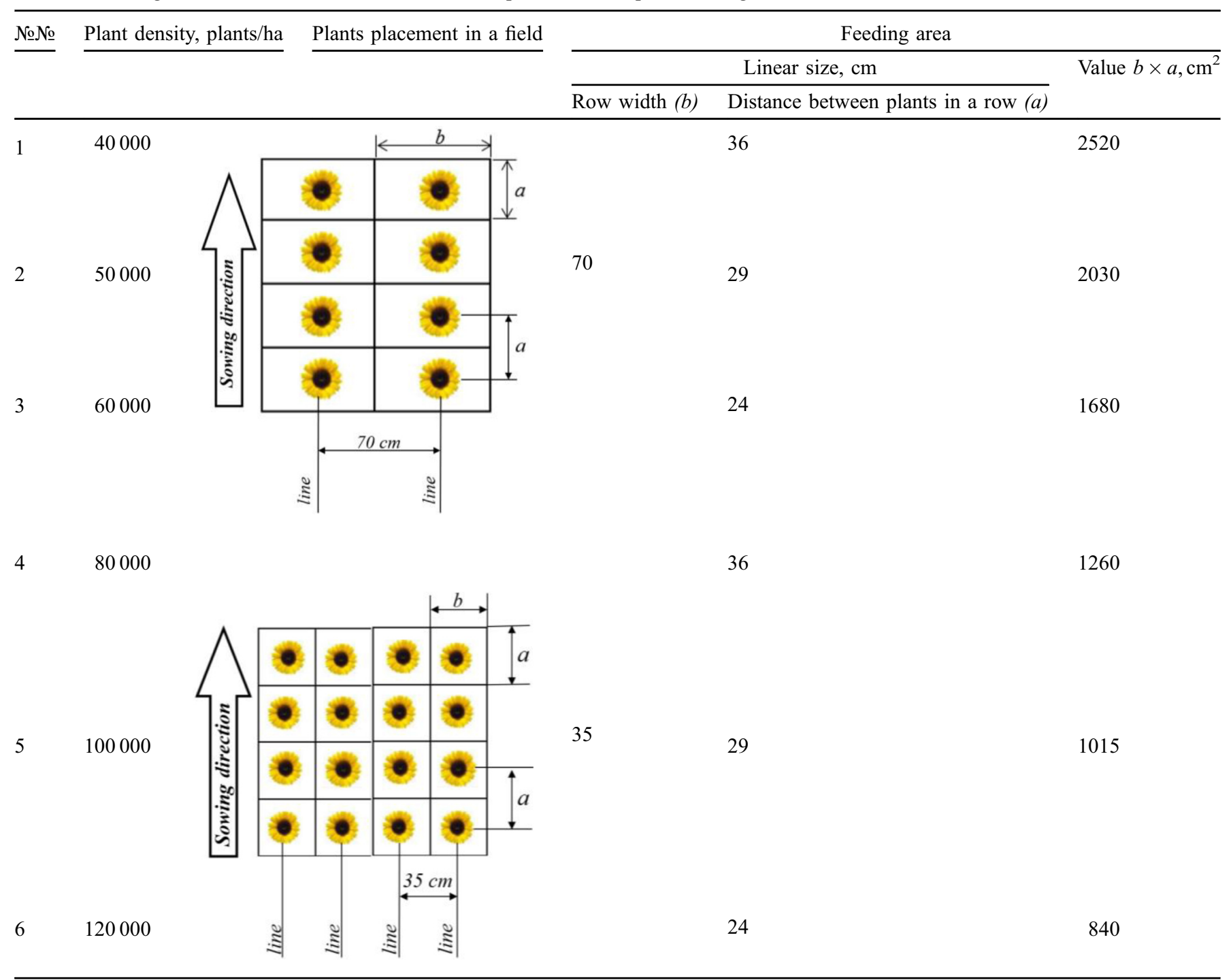

In the experiments we studied the effect of a plant density $(80000,100000$, and 120000 plants/ha) on biometric characteristics, productivity, and quality of sunflower yield in wide-row planting with the width of $35 \mathrm{~cm}$. Henceforward, under the notion of "a plant density", the authors mean the number of plants on an area of 1 ha $\left(10000 \mathrm{~m}^{2}\right)$, that is, the density of their placement in the sowing.

We studied six hybrids in a field experiment: a) common non-erectoid: 1) Triumph; 2) Berkut; b) with erectoid leaf type: 3) Triumph er-2; 4) Triumph Er-3; 5) Berkut er-2; 6) Berkut Er3 . In addition, we used three densities, plants/ha: 1) $80000 ; 2$ ) 100000 ; 3) 120000 . We used manual sowing in the first ten days of May. The experiment was arranged in 3 blocks (replicates) with the 6 genotypes planted in the same order in each block but a systematic shift of the 3 crop densities in each block. The total plot area was $15.75 \mathrm{~m}^{2}$, the recording area was $3.15 \mathrm{~m}^{2}$. The plot was five-row. To exclude the impact of the edge effect, we took into account the middle (third) row for yield recording and did not included in there the first and last plants of the row. The yield was corrected to $100 \%$ purity and standard $10 \%$ seed moisture.

\section{Results and discussion}

In the presowing period of 2018 (from October 2017 to March 2018), the amount of precipitation was $455 \mathrm{~mm}$, exceeding the level of long-term annual average values by $40 \%$. It led to an accumulation of a sufficient supply of water in the soil. The precipitation $(86 \mathrm{~mm})$ and the high average daily temperature $\left(19.0^{\circ} \mathrm{C}\right)$ in May contributed to the intensive seed germination and the development of even sunflower seedlings (Tabs. 2 and 3).

In the period from the first pair of true leaves to the appearance of a sunflower head (June), there was a relative precipitation deficit $(11 \mathrm{~mm})$ and a high average daily temperature $\left(23.5^{\circ} \mathrm{C}\right)$. The period from budding to the beginning of flowering (July) took place in the conditions of abundant precipitation $(119 \mathrm{~mm})$ and high average daily 


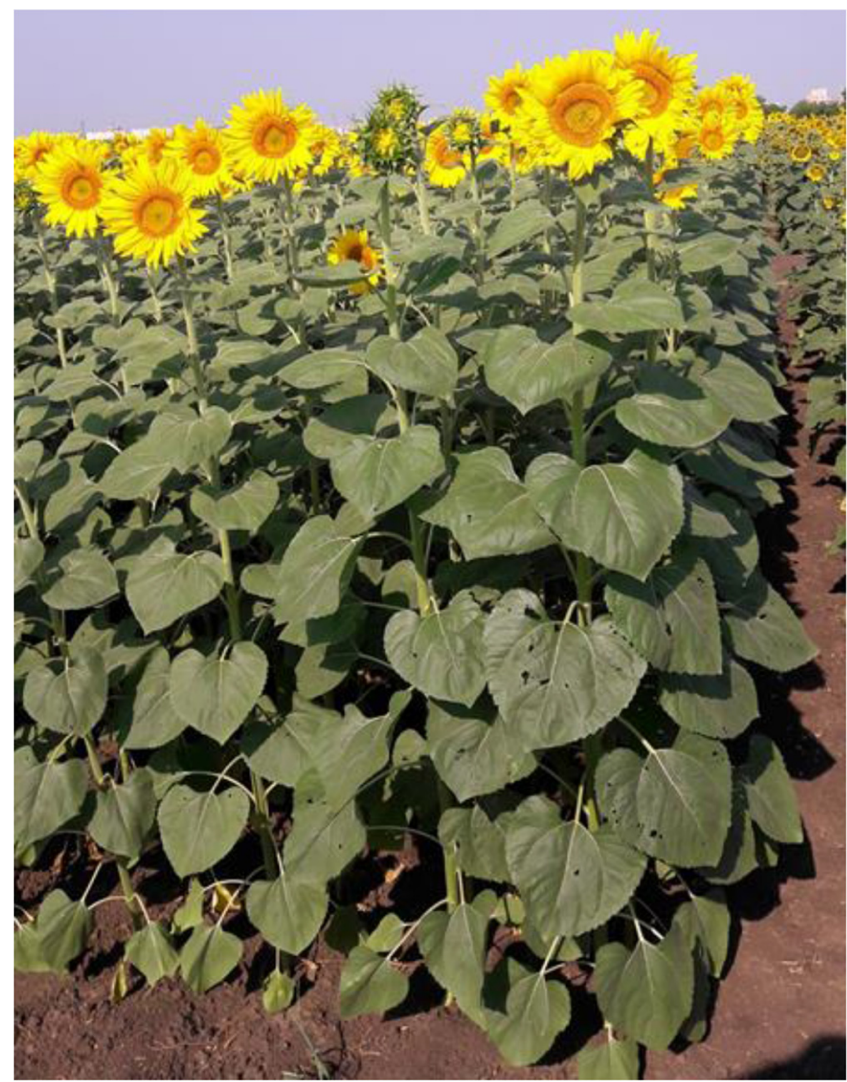

Fig. 3. Hybrid Triumph.

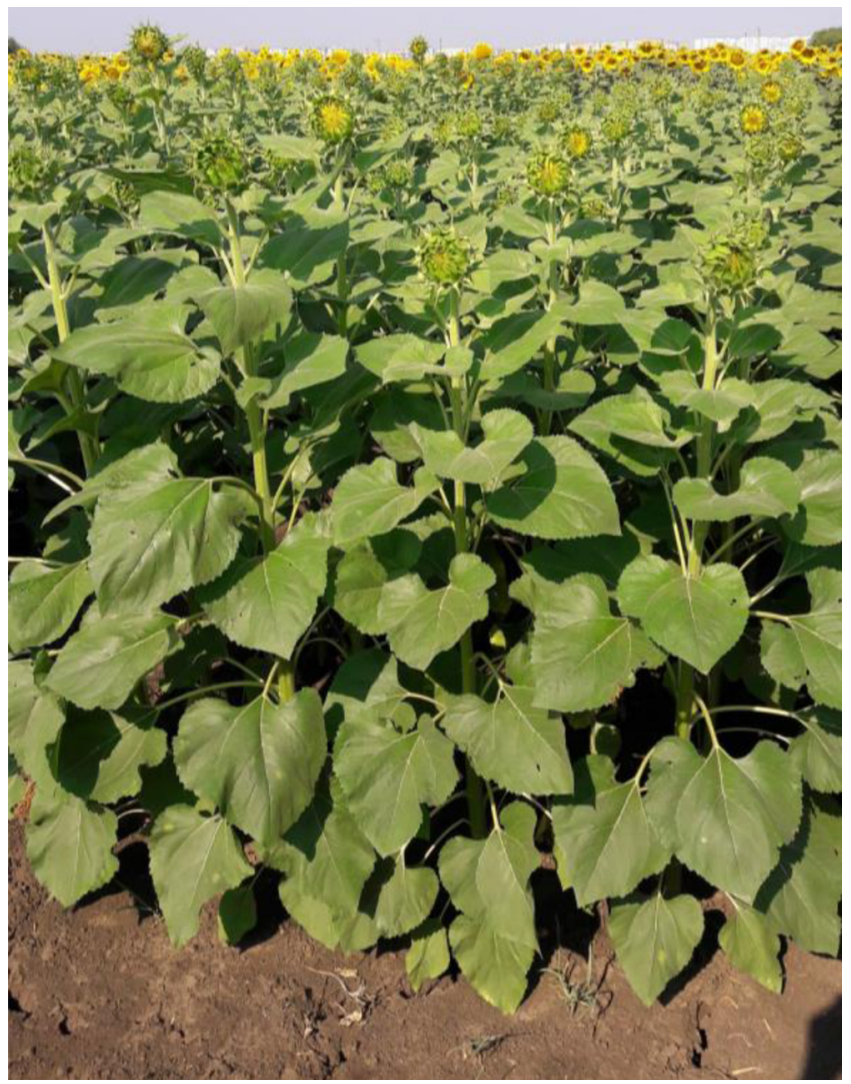

Fig. 4. Hybrid Berkut.

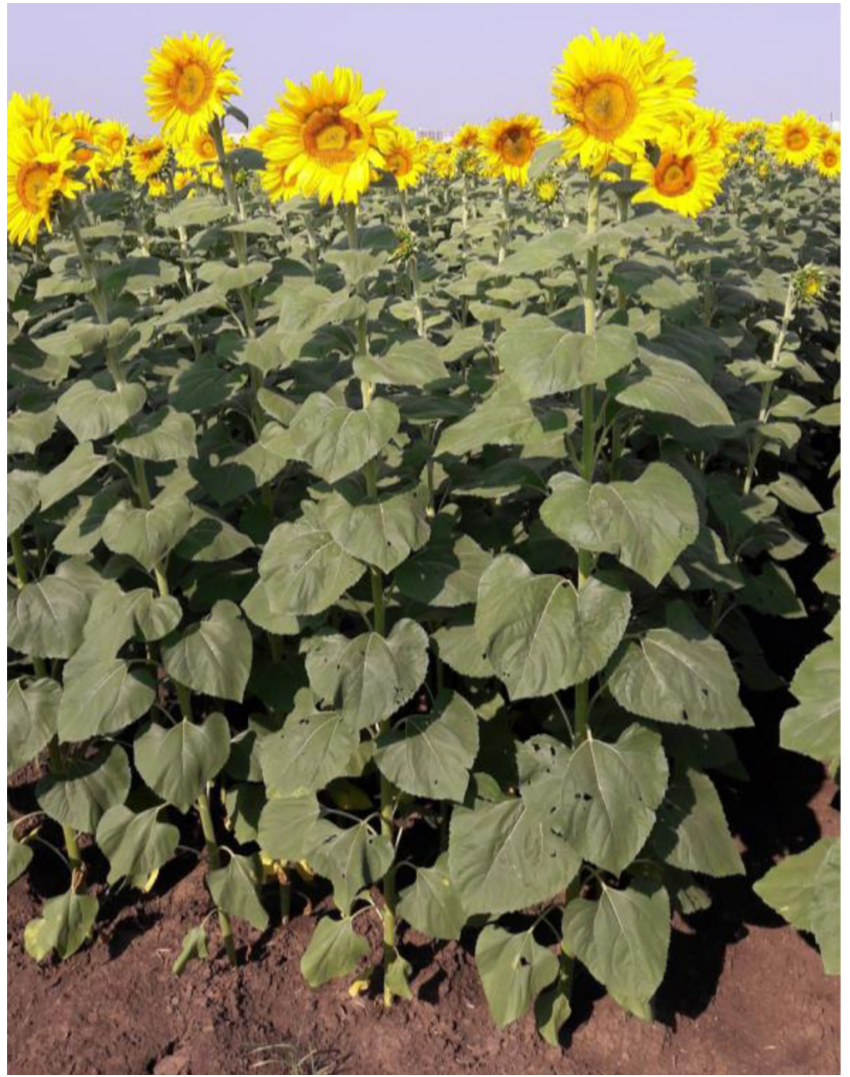

Fig. 5. Hybrid Triumph er-2.

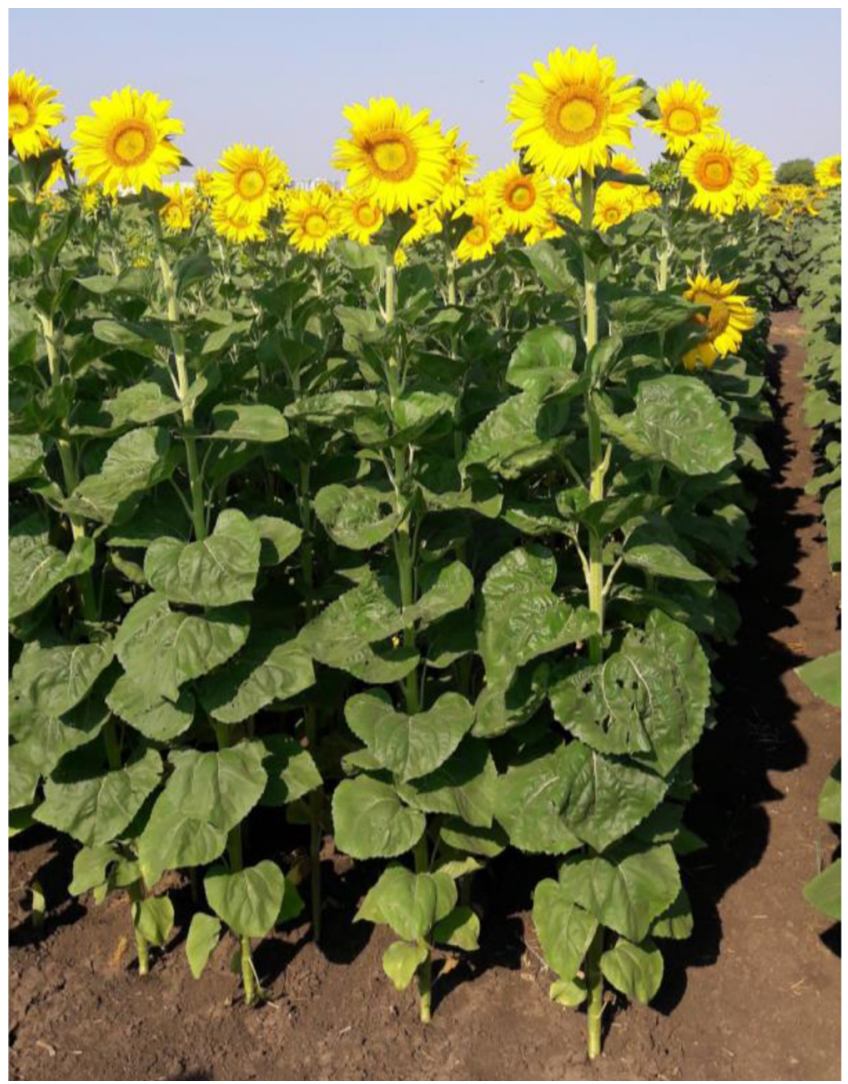

Fig. 6. Hybrid Triumph Er-3. 


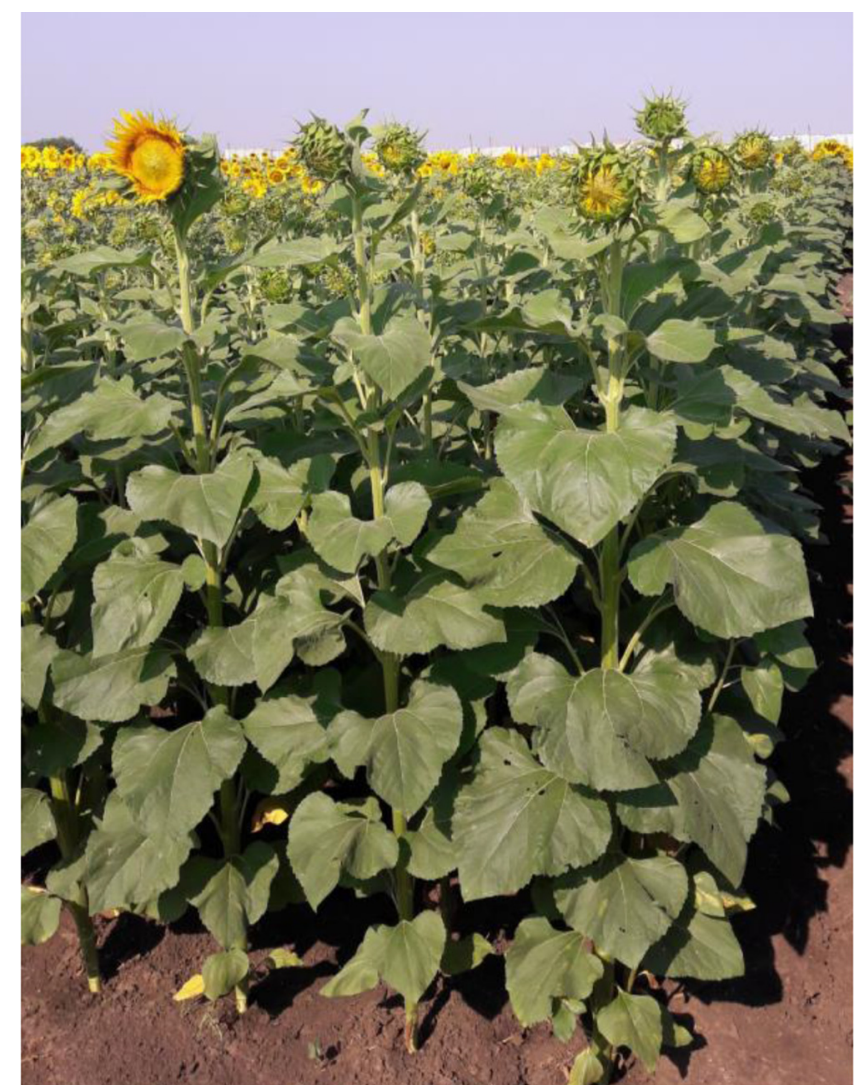

Fig. 7. Hybrid Berkut er-2.

temperature $\left(26.3^{\circ} \mathrm{C}\right)$, which exceeded the long-term annual average norm by $3.1^{\circ} \mathrm{C}$. During the growth and seed filling stages (August), it was warm $-25.4^{\circ} \mathrm{C}$, but only $6.8 \mathrm{~mm}$ of precipitation fell. The sunflower ripening (September) took place at an average daily temperature of $19.5^{\circ} \mathrm{C}$ with a large amount of precipitation $(80 \mathrm{~mm})$. An abnormally high temperature in June and July, exceeding the long-term annual average values by $3.1^{\circ} \mathrm{C}$, as well as a water deficit in June and August (19.4 and $14.2 \%$ of the long-term annual average values), could have a negative impact on the development of sunflower yield.

In 2019, the conditions for seed germination and emergence of seedlings were favorable due to the sufficient water supply in the soil accumulated in the period from October 2018 to March 2019 (324 mm), high temperature $\left(19.3^{\circ} \mathrm{C}\right)$ and abundant precipitation $(68 \mathrm{~mm})$ in May. The period from the emergence of sunflower seedlings to the beginning of budding (June) was characterized by severe water shortage due to insufficient water supply from the atmospheric precipitation (16.0\% of the long-term annual average values) and high average daily temperature $\left(25.1^{\circ} \mathrm{C}\right)$. During the budding stage of sunflower, the average daily temperature was at the normal level $\left(23.0^{\circ} \mathrm{C}\right)$, and the amount of precipitation exceeded the long-term annual average values by 2.2 times. The weather conditions during the critical phase for sunflower from the beginning of flowering to the seed filling (July) contributed to the development of culture. The amount of precipitation in August and September exceeded the long-term

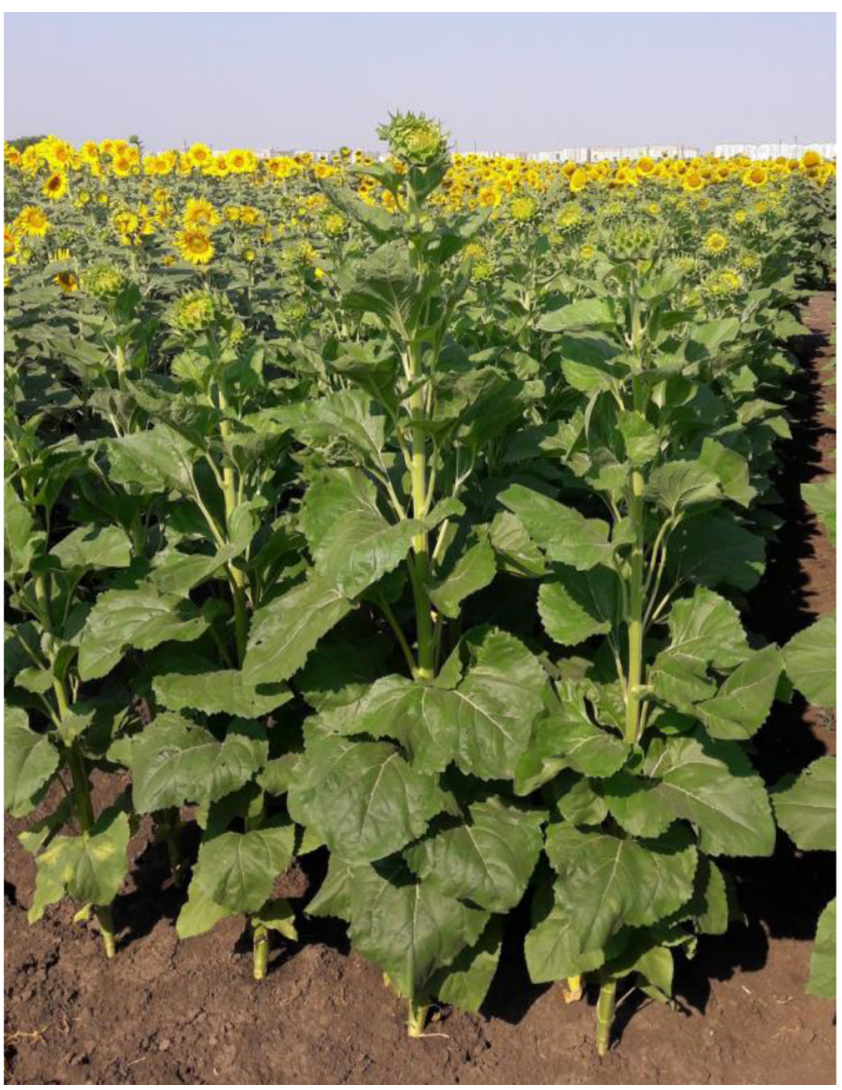

Fig. 8. Hybrid Berkut Er-3.

annual average values by $15-18 \%$, and the temperature differed from those values by $0.1-0.8^{\circ} \mathrm{C}$.

Henceforward, by the "Triumph group" we mean the normal Triumph hybrid and the erectoid hybrids Triumph er-2 and Triumph Er-3; by the "Berkut group" we mean the normal Berkut hybrid and the erectoid hybrids Berkut er- 2 and Berkut Er-3. In 2018, the height of the hybrids of Triumph group was within 165.3-175.0 cm, and the height was $152.0-163.3 \mathrm{~cm}$ for Berkut group (Tab. 4). In 2019, the hybrids height was slightly lower: for the Triumph group it was $150.7-161.3 \mathrm{~cm}$, for the Berkut group it was $142.2-153.9 \mathrm{~cm}$. In 2018 , the height of the erectoid hybrid Triumph Er-3 was significantly less than that of the normal Triumph at the density of 100000 and 120000 plants/ha, in $2019-$ at 80000 plants/ha. The erectoid hybrid Berkut er-2 was in all cases higher than the normal Berkut, and in 2018, this difference was significant at the density of 80000 plants/ha, in 2019-at 80000 and 100000 plants/ha. Each year, all the Triumph hybrids broke into blossom five days earlier than the Berkut hybrids.

The head diameter of the Triumph group hybrids was 13.7$15.7 \mathrm{~cm}$ in 2018 , and $12.8-15.4 \mathrm{~cm}$ in 2019 . The erectoid hybrid Triumph Er-3 had the smallest head, and in 2019, at the density of 80000 plants/ha, the head diameter of this hybrid was significantly lower (by $1.2 \mathrm{~cm}$ ) than that of the normal Triumph.

The Berkut group hybrids have a larger head, its diameter in 2018 ranged from 14.0 to $16.7 \mathrm{~cm}$, in 2019 -from 14.2 to $16.4 \mathrm{~cm}$. With an increase in the density from 80000 to 
Table 2. Distribution of precipitation during the growth season of sunflower (mm). The weather station of VNIIMK, Krasnodar.

\begin{tabular}{|c|c|c|c|c|c|c|c|}
\hline \multirow[t]{2}{*}{ Year } & \multirow{2}{*}{$\begin{array}{l}\text { Amount of precipitation } \\
\text { for October-March }\end{array}$} & \multicolumn{5}{|c|}{ Month } & \multirow{2}{*}{$\begin{array}{l}\text { Amount of precipitation for } \\
\text { May-September }\end{array}$} \\
\hline & & May & June & July & August & September & \\
\hline 2018 & 455 & 86 & 11 & 119 & 7 & 80 & 303 \\
\hline
\end{tabular}

Table 3. Average daily temperature during the growth season of sunflower $\left({ }^{\circ} \mathrm{C}\right)$. The weather station of VNIIMK, Krasnodar.

\begin{tabular}{lllllll}
\hline \multirow{2}{*}{ Year } & \multicolumn{4}{c}{ Month } & Average temperature for May-September \\
\cline { 2 - 6 } & May & June & July & August & September & \\
\hline \multirow{2}{*}{ Long-term annual average } & 16.8 & 20.4 & 23.2 & 23.7 & 17.3 & 20.3 \\
2018 & 19.0 & 23.5 & 26.3 & 25.4 & 19.5 & 22.7 \\
2019 & 19.3 & 25.1 & 23.0 & 23.6 & 18.2 & 21.8 \\
\hline
\end{tabular}

Table 4. Effect of a plant density on the biometric characteristics of plants of normal and erectoid sunflower hybrids.

\begin{tabular}{|c|c|c|c|c|c|}
\hline \multicolumn{2}{|c|}{ Variant } & \multicolumn{2}{|c|}{ Plant height, $\mathrm{cm}$} & \multicolumn{2}{|c|}{ Head diameter, $\mathrm{cm}$} \\
\hline \multirow[t]{3}{*}{80000} & Triumph & 170.0 & 159.9 & 14.7 & 15.4 \\
\hline & Triumph Er-3 & 170.0 & 151.8 & 14.3 & 14.2 \\
\hline & $\mathrm{LSD}_{05}$ & 3.8 & 2.6 & 2.5 & 0.8 \\
\hline \multirow{2}{*}{100000} & Triumph Er-3 & 167.7 & 152.1 & 14.3 & 13.2 \\
\hline & $\mathrm{LSD}_{05}$ & 2.5 & 13.5 & 2.5 & 2.4 \\
\hline \multirow[t]{3}{*}{120000} & Triumph & 169.3 & 158.7 & 14.7 & 13.7 \\
\hline & Triumph er-2 & 172.7 & 157.6 & 14.7 & 13.8 \\
\hline & Triumph Er-3 & 165.3 & 150.7 & 13.7 & 12.8 \\
\hline 80000 & $\mathrm{LSD}_{05}$ & 8.9 & 3.7 & 2.5 & 2.2 \\
\hline \multirow[t]{4}{*}{100000} & Berkut & 160.0 & 142.2 & 15.3 & 15.9 \\
\hline & Berkut er-2 & 163.3 & 153.9 & 15.0 & 15.5 \\
\hline & Berkut Er-3 & 154.7 & 147.9 & 15.0 & 15.9 \\
\hline & $\mathrm{LSD}_{05}$ & 6.6 & 5.4 & 2.0 & 2.5 \\
\hline \multirow[t]{4}{*}{120000} & Berkut & 160.7 & 146.1 & 14.0 & 14.2 \\
\hline & Berkut er-2 & 161.0 & 148.3 & 14.3 & 14.2 \\
\hline & Berkut Er-3 & 154.3 & 144.7 & 14.3 & 15.3 \\
\hline & $\mathrm{LSD}_{05}$ & 8.0 & 7.0 & 1.5 & 4.2 \\
\hline
\end{tabular}


Table 5. Effect of a plant density on the thousand-seed weight (g) of normal and erectoid sunflower hybrids.

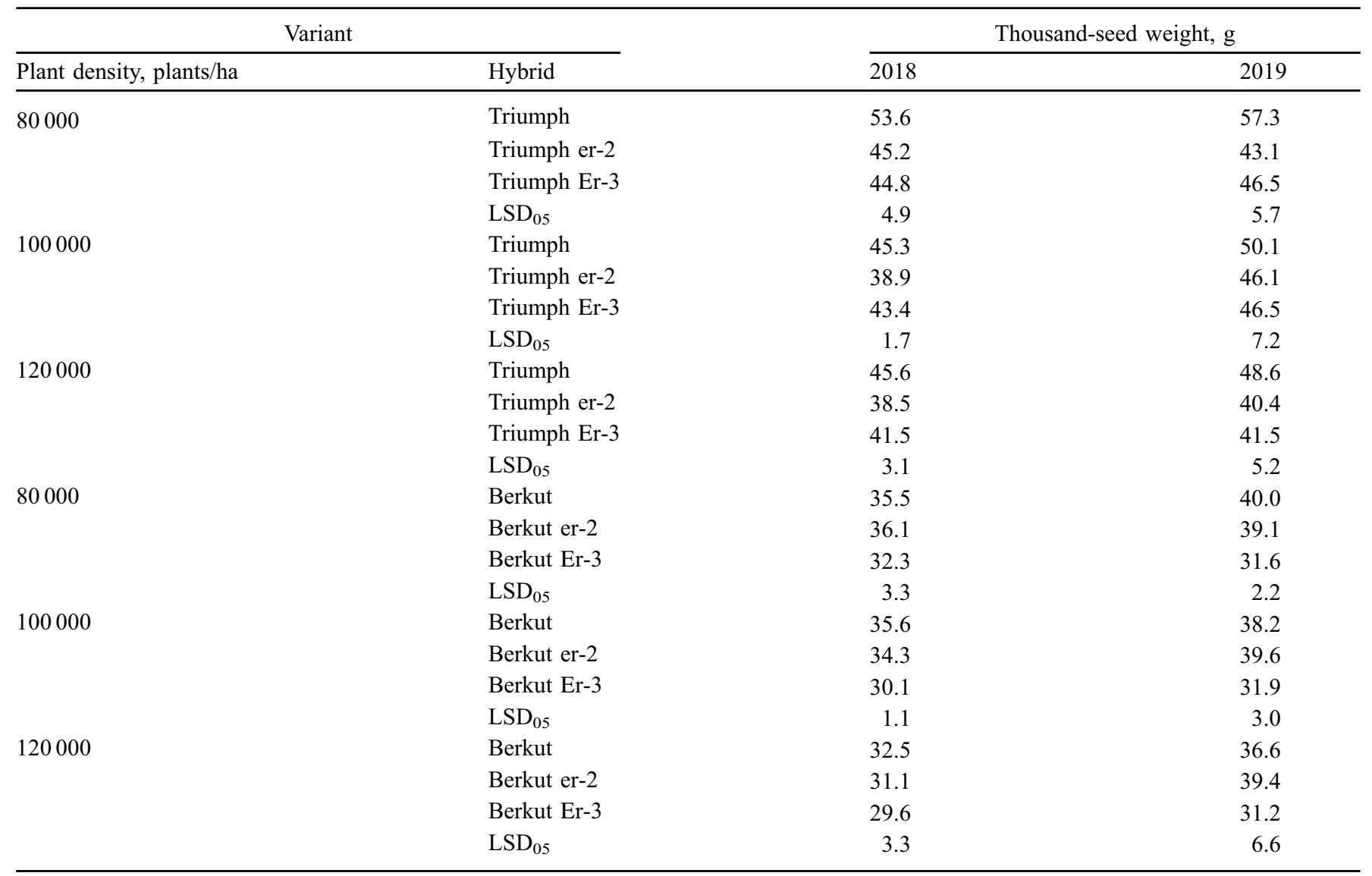

120000 plants/ha, we observed a decrease in the head diameter by $0.1-2.7 \mathrm{~cm}$, however, in 2019 , we noted the largest head diameter $(15.9 \mathrm{~cm})$ in the erectoid hybrid Berkut Er-3 at the density of $100000 \mathrm{plants} / \mathrm{ha}$. There was no significant difference between the head size of normal and erectoid hybrids.

Despite the relatively small head diameter, the seeds of the Triumph group hybrids were larger than those of the Berkut group. In 2018, the thousand-seed weight of the Triumph group hybrids was $38.5-53.6 \mathrm{~g}$, in $2019-40.4-57.3 \mathrm{~g}$ (Tab. 5). Regardless of the plant density, the seeds of the erectoid hybrids Triumph er- 2 and Triumph Er-3 were smaller than those of the normal Triumph hybrid. Only in 2019, at the density of $100000 \mathrm{plants} / \mathrm{ha}$, the exceedance of the thousandseed weight of the normal hybrid over the erectoid ones was below the $\mathrm{LSD}_{05}$ level, in other cases, the seeds of the normal hybrid were significantly larger. As the plant density increased, the thousand-seed weight, as a rule, decreased.

In 2018, the Berkut group hybrids had the thousand-seed weight of $29.6-36.1 \mathrm{~g}$, in $2019-31.2-40.0 \mathrm{~g}$. The differences in this indicator between the normal Berkut hybrid and erectoid hybrid Berkut er-2 were insignificant (except for the variant with the density of 100000 plants/ha in 2018). The erectoid hybrid Berkut Er-3 had the smallest seeds; the differences in the thousand-seed weight between this hybrid and the normal Berkut hybrid were especially evident at the density of 80000 and 100000 plants/ha.
In 2018, after two days of heavy precipitation (July 16, 2016-21 mm and July 17, 2018-53 mm), which were accompanied by wind gusts up to $6.1-6.5 \mathrm{~m} / \mathrm{s}$, we noted the lodging and breaking of plant stems to varying degrees in different hybrids (Fig. 9). In our opinion, the nature of these phenomena is due to both atmospheric effects and genetic characteristics.

It is known that lodged plants, as well as plants those stems are broken in the middle or lower part, do not get into the harvester's thresher during the mechanized harvesting, which leads to a decrease in the bulk yield. Therefore, in 2019, we determined the values of lodging and breaking of stems of the studied hybrids. The Triumph group hybrids were more durable, the number of breaks in their stems did not exceed $0.7 \%$. We observed the stem breaks much more often in the Berkut group hybrids: $7.1 \%$ in the normal Berkut hybrid, 4.4 and $5.1 \%$ in the erectoid hybrids Berkut er-2 and Berkut Er-3, respectively. Most of the breaks occurred in the upper part of a stem. There were little breaks in the middle part of a stem $(0.2 \%$ in Berkut er- 2 genotype), and there were no breaks in the lower part of the stems.

The lodging of the Triumph group hybrids was significant and amounted to $6.4 \%$ in the normal Triumph genotype, and to 30.2 and $10.9 \%$ in the erectoid hybrids Triumph er-2 and Triumph Er-3, respectively. The sunflower lodging in Berkut group hybrids was much less and did not exceed $0.7 \%$. Therefore, the negative quality of erectoid hybrids in some 


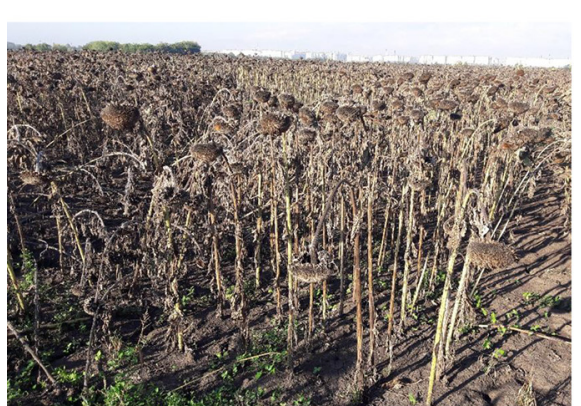

a)

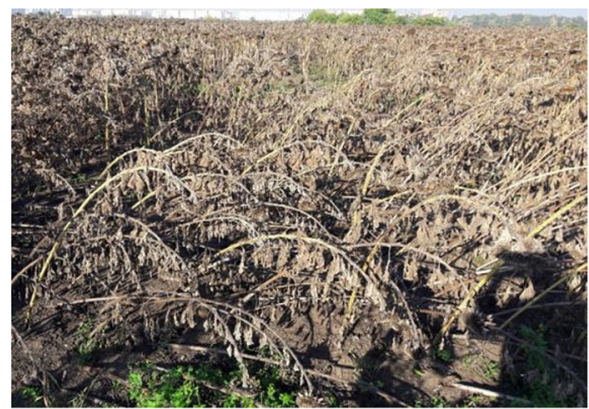

b)

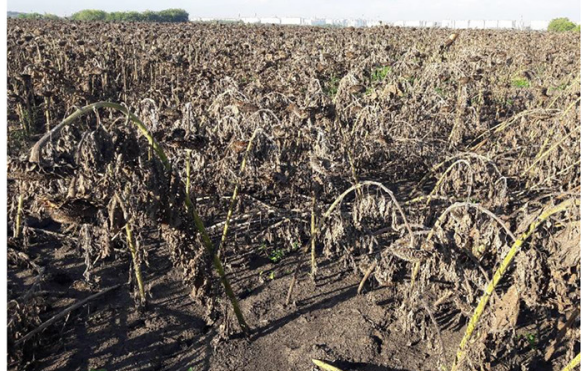

c)

Fig. 9. Manifestation of lodging in different sunflower hybrids: a: Berkut Er-3; b: Triumph er-2; c: Triumph Er-3 (2018).

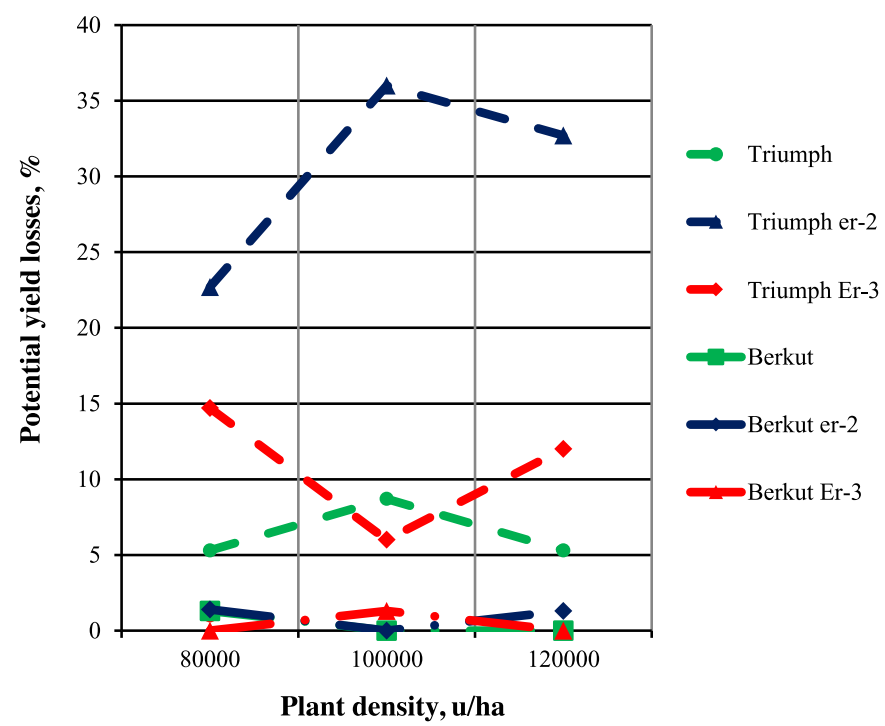

Fig. 10. Potential yield losses of sunflower genotypes during combine harvesting due to lodging (2019).

cases may be the high lodging capacity of plants of some genotypes, which is especially clearly manifested in a squally wind accompanied by intense precipitation.

The highest potential yield losses from non-threshing of lodged and broken plants were in the Triumph Er-3 and Triumph er-2 genotypes, reaching 14.7 and $36.0 \%$, respectively (Fig. 10). Probably, the erectoid types are more affected by lodging than normal types due to pleiotropy of erectoid genes on root and stem structure.

The most important economic characteristic is the yield, and breeding and agrotechnical methods are used to increase it. We used two methods in our work: the first is fundamentally new genotypes with a compact habitus, enabling to sow plants close to each other; the second is a plant density as an agrotechnical tool for increasing crop productivity. In our opinion, it is the combination of these two components that should ensure an increase in crop yield (Fig. 11). We expected a very quick effect, but, as the above mentioned data showed, the obtaining of the expected result was complicated both by a change in the yield structure and the non-resistance of some erectoid genotypes to atmospheric phenomena in the form of rain with gusts of wind.

Despite this, in general, the crop yield obtained in the experiment was above the average for the region $(2.41 \mathrm{t} / \mathrm{ha})$ over the past five years (2015-2019). In 2018, the yield of the Triumph group hybrids $(2.48-3.24 \mathrm{t} / \mathrm{ha})$ was within that of the Berkut group hybrids $-2.30-3.63 \mathrm{t} / \mathrm{ha}$. In 2019 , we recorded a decrease in the yield of the Triumph group hybrids to 1.93-2.98 $\mathrm{t} /$ ha and of the Berkut group hybrids to $2.04-3.15 \mathrm{t} / \mathrm{ha}$ (Tab. 6), due to the extreme weather conditions, when in the period from the emergence of sunflower seedlings to the beginning of budding, only $17 \mathrm{~mm}$ of precipitation fell, and the average daily temperature exceeded the long-term annual average values by $4.7^{\circ} \mathrm{C}$.

In 2018, the highest yield of the erectoid hybrids Triumph er2 and Triumph Er-3 was at the density of 100000 plants/ha - 3.06 and $3.24 \mathrm{t} /$ ha, respectively, which is significantly higher than the yield of the normal Triumph hybrid $-2.47 \mathrm{t} / \mathrm{ha}$. The decrease in the density to 80000 plants/ha led to a decrease in the yield of erectoid genotypes to 2.94 and $2.48 \mathrm{t} /$ ha, respectively, and an increase in the yield of the normal hybrid to $3.20 \mathrm{t} / \mathrm{ha}$, while the increase to $120000 \mathrm{plants} / \mathrm{ha}$ neutralized the difference in the yield of genotypes. In 2019, at the density of 80000 plants/ha, the yield of the erectoid hybrids Triumph er-2 and Triumph Er-3 was 2.62 and $2.98 \mathrm{t} / \mathrm{ha}$, respectively, significantly exceeding the yield of the normal Triumph genotype $-2.37 \mathrm{t} / \mathrm{ha}$. The increase in the density to 100000 and 120000 plants/ha decreased the yield of all hybrids, however, the erectoid hybrid Triumph er- 2 had the advantage -2.47 and $2.70 \mathrm{t} / \mathrm{ha}$, respectively.

The productivity analysis of the Berkut group hybrids established that in 2018, at the density of 80000 plants/ha, the erectoid hybrid Berkut had the highest productivity $-3.15 \mathrm{t} / \mathrm{ha}$, which is significantly higher than the productivity of the normal hybrid Berkut $(2.84 \mathrm{t} / \mathrm{ha})$. At the densities of 100000 and 120000 plants/ha, the normal hybrid Berkut had significant yield advantages over the erectoid Berkut er-2: 3.63 and $3.48 \mathrm{t} / \mathrm{ha}$ versus 2.70 and $2.74 \mathrm{t} / \mathrm{ha}$, respectively. Under the conditions of 2019, at the density of 80000 plants/ha, the normal Berkut genotype had the highest yield $-3.15 \mathrm{t} / \mathrm{ha}$, which significantly exceeds the yield of the Berkut er-2 and Berkut Er-3 genotypes -2.79 and $2.04 \mathrm{t} / \mathrm{ha}$, respectively. The densification of planting to 100000 and 120000 plants/ha led to a decrease in the productivity of the Berkut hybrid to 2.75 and $2.56 \mathrm{t} / \mathrm{ha}$. The productivity of the erectoid hybrid Berkut er-2 was insignificantly affected by the increase in the density to 100000 plants/ ha, however, with its further increase to 120000 , there was a significant increase in the productivity to $3.13 \mathrm{t} / \mathrm{ha}$. The differences in the productivity of the normal Berkut genotype and the erectoid Berkut Er-3 were insignificant. 

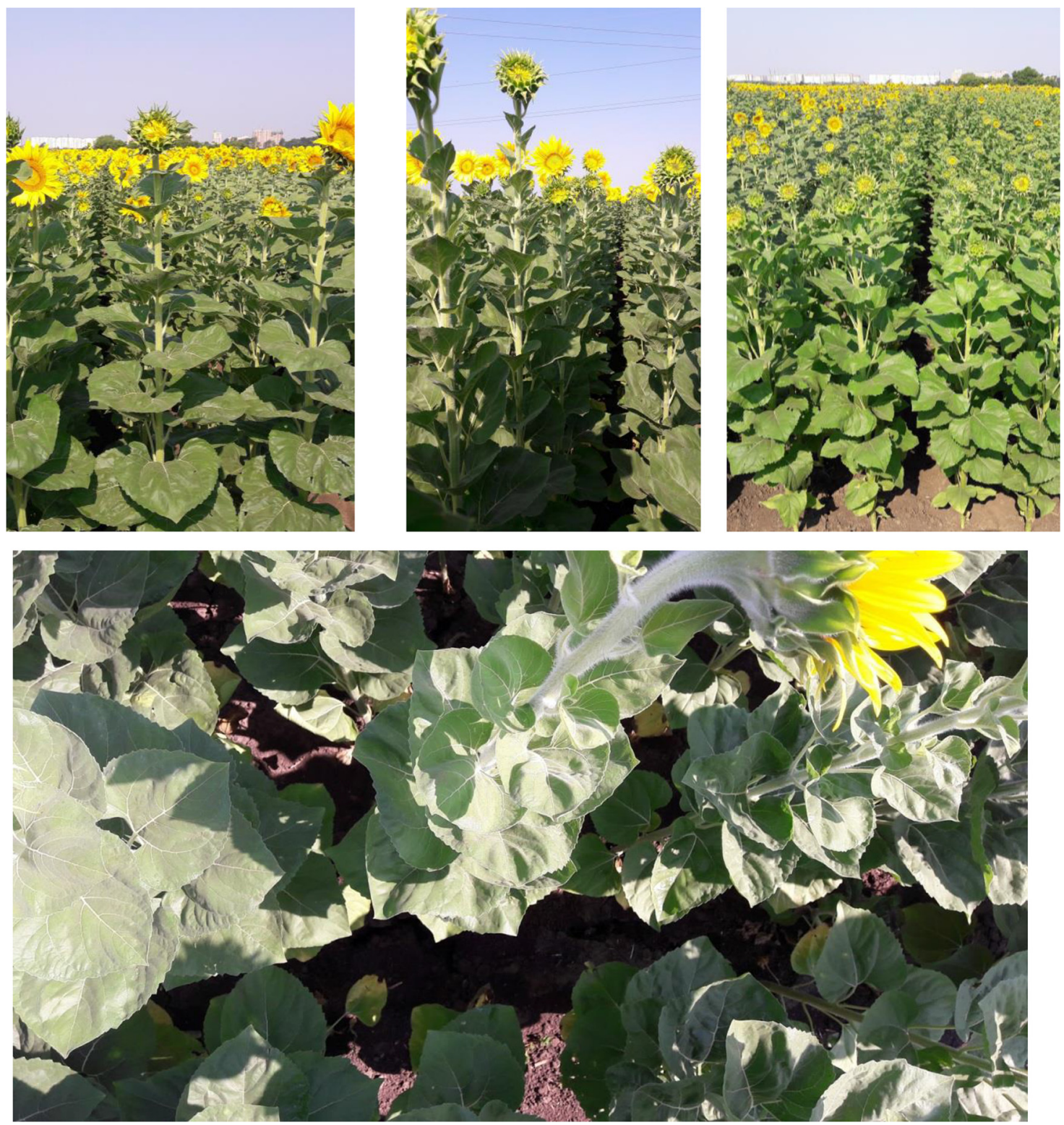

Fig. 11. Interplanting of sunflower hybrids with a compact habitus.

The different sunflower growing conditions in 2018-2019 affected the oil content of seeds, which in 2019 in most cases was higher than in 2018. The highest response to the weather conditions was manifested in the Berkut er-2 and Berkut hybrids, where the change in oil content of seeds was 1.4-2.1 and $1.2-1.9 \%$, respectively. In 2019 , the oil content of seeds of hybrids Triumph, Triumph er-2 and Triumph Er-3 changed insignificantly compared to 2018 - by $0.1-0.7,0.4-0.6$ and $0.6-0.9 \%$, respectively. The sunflower hybrid Berkut had the highest oil content of seeds: in 2018-51.1-52.2\%, in 2019-52.3-53.4\%. Depending on the plant density, the oil content of seeds varied insignificantly. Only in the erectoid hybrid Berkut Er-3 at the density of 120000 plants/ha the values of this indicator in both years of research were significantly lower than that of the normal Berkut.

\section{Conclusion}

The cultivation of sunflower hybrids with normal and erectoid leaf types on leached chernozem of the Western Ciscaucasia in wide-row sowings with $35 \mathrm{~cm}$ width and the density of 100 000-120 000 plants/ha leads to a decrease in the plant height, thousand-seed weight, productivity, and oil content of seeds. Therefore, the compact habitus of sunflower plants is not a determining factor in the development of the productivity of sowings with a high plant density. The natural resources of the environment allow to achieve high productivity and product quality in sowings with the density not exceeding 80000 plants/ha. 
Table 6. Effect of a plant density on the productivity and oil content of seeds of normal and erectoid sunflower hybrids.

\begin{tabular}{|c|c|c|c|c|c|}
\hline \multicolumn{2}{|c|}{ Variant } & \multicolumn{2}{|c|}{ Productivity, $\mathrm{t} / \mathrm{ha}$} & \multicolumn{2}{|c|}{ Oil content of seeds, $\%$} \\
\hline Plant density, plants/ha & Hybrid & 2018 & 2019 & 2018 & 2019 \\
\hline \multirow[t]{4}{*}{80000} & Triumph & 3.20 & 2.37 & 48.7 & 49.3 \\
\hline & Triumph er-2 & 2.94 & 2.62 & 48.8 & 49.4 \\
\hline & Triumph Er-3 & 2.48 & 2.98 & 48.8 & 49.7 \\
\hline & $\mathrm{LSD}_{05}$ & 0.54 & 0.07 & 0.71 & 0.77 \\
\hline \multirow[t]{4}{*}{100000} & Triumph & 2.47 & 1.93 & 49.0 & 49.7 \\
\hline & Triumph er-2 & 3.06 & 2.47 & 48.1 & 48.9 \\
\hline & Triumph Er-3 & 3.24 & 2.31 & 49.3 & 49.9 \\
\hline & $\mathrm{LSD}_{05}$ & 0.28 & 0.23 & 1.48 & 1.45 \\
\hline \multirow[t]{4}{*}{120000} & Triumph & 2.86 & 2.11 & 49.2 & 49.1 \\
\hline & Triumph er-2 & 2.84 & 2.70 & 49.1 & 49.5 \\
\hline & Triumph Er-3 & 2.84 & 2.00 & 49.2 & 50.1 \\
\hline & $\mathrm{LSD}_{05}$ & 0.48 & 0.08 & 0.70 & 1.06 \\
\hline \multirow[t]{4}{*}{80000} & Berkut & 2.84 & 3.15 & 51.8 & 53.4 \\
\hline & Berkut er-2 & 3.15 & 2.79 & 52.0 & 53.4 \\
\hline & Berkut Er-3 & 2.95 & 2.04 & 51.3 & 52.4 \\
\hline & $\mathrm{LSD}_{05}$ & 0.27 & 0.35 & 1.38 & 1.34 \\
\hline \multirow[t]{4}{*}{100000} & Berkut & 3.63 & 2.75 & 51.1 & 53.0 \\
\hline & Berkut er-2 & 2.70 & 2.56 & 51.1 & 53.1 \\
\hline & Berkut Er-3 & 2.30 & 2.53 & 51.6 & 52.3 \\
\hline & $\mathrm{LSD}_{05}$ & 0.24 & 0.23 & 0.74 & 0.87 \\
\hline \multirow[t]{4}{*}{120000} & Berkut & 3.48 & 2.56 & 52.2 & 53.4 \\
\hline & Berkut er-2 & 2.74 & 3.13 & 51.2 & 53.3 \\
\hline & Berkut Er-3 & 2.50 & 2.58 & 51.4 & 52.6 \\
\hline & $\mathrm{LSD}_{05}$ & 0.57 & 0.21 & 0.6 & 0.62 \\
\hline
\end{tabular}

\section{References}

Aksyonov I. 2007. Effect of cultivation measures on index of photosynthesis and yield of sunflower. Helia 30(47): 79-86.

Barros JFC, Carvalho MD, Basch G. 2004. Response of sunflower (Helianthus annuus L.) to sowing date and plant density under Mediterranean conditions. Eur J Agron 21(3): 347-356.

Calviño P, Sadras VO, Redolatti M, Canepa M. 2004. Yield responses to narrow rows as related to interception of radiation and water deficit in sunflower hybrids of varying cycle. Field Crops Res 88 (2-3): 261-267.

Demurin YN, Tolmachyova NN. 2005. The identification of erectoid leaf genes in sunflower. Oil Crops Sci Tech Bull Vniimk 2(133): $7-11$.

Echarte L, Della Maggiora A, Cerrudo D, et al. 2011. Yield response to plant density of maize and sunflower intercropped with soybean. Field Crops Res 121(3): 423-429.

EL-Satar MAA, Ahmed AA-E, Hassan THA. 2017. Response of seed yield and fatty acid compositions for some sunflower genotypes to plant spacing and nitrogen fertilization. Inform Process Agric 4 (3): 241-252.

Hall AJ, Sposaro MM, Chimenti CA. 2010. Stem lodging in sunflower: Variations in stem failure moment of force and structure across crop population densities and post-anthesis developmental stages in two genotypes of contrasting susceptibility to lodging. Field Crops Res 116(1-2): 46-51.

Ibrahim HM. 2012. Response of some sunflower hybrids to different levels of plant density. In: APCBEE Procedia-International conference on Asia Agriculture and Animal, July 23-24, Singapore, pp. 175-182.

Kurbanov SA, Magomedova DS, Karaeva LY. 2018. The effect of a plant density of sunflower plants on infestation of its sowings and productivity. Agr Russ 10: 28-31.

López-Pereira M, Connor DJ, Hall AJ. 2020. Intercepted radiation and radiation-use efficiency in sunflower crops grown at conventional and wide inter-row spacings: Measurements and modeled estimates of intercepted radiation. Field Crops Res 246: 107684.

Ludanova EV, Malay NF, Shurupov VG. 2015. The effect of a plant density on sunflower productivity. News High Educ Inst. North Cauc Reg. Ser: Nat Sci 4(188): 101-103.

Lukomets VM, ed. 2010. Methods of conducting field agrotechnical experiments with oil crops, 2nd ed., revised and supplemented. Krasnodar, pp. 238-245.

Lukomets VM, Tishkov NM. 2019. Productivity of the maternal forms of sunflower hybrids depending on plant populations. Oil Crops 1(177): 40-47.

Skaloud V, Kovacik A. 1992. Study of inheritance of progressive sunflower plant traits in relation to stand density. Helia 15(17): $25-32$.

Soleymani A. 2017. Light response of sunflower and canola as affected by plant density, plant genotype and $\mathrm{N}$ fertilization. J Photochem Photobiol B: Biol 173: 580-588.

Steer BT, Coaldrake PD, Pearson CJ, Canty CP. 1986. Effects of nitrogen supply and population density on plant development and yield components of irrigated sunflower (Helianthus annuus L.). Field Crops Res 13: 99-115. 
Tishkov NM, Shkarupa MV. 2020. Influence of plant population on yield and yield structure of maternal forms of sunflower hybrids. Oil Crops 1(181): 70-78.

Tolmachyova NN, Demurin YN. 2008. The genetic control of erectoid leaf in the sunflower line L1389. Oil Crops (Sci Tech Bull VNIIMK) 2(139): 12-15.

Vedmedeva EV, Tolmachyov VV. 2001. New marker morphological characteristics of sunflower. Sci Tech bull VNIIMK 124: 31-33.

Villalobos FJ, Sadras VO, Soriano A, Fereres E. 1994. Planting density effects on dry matter partitioning and productivity of sunflower hybrids. Field Crops Res 36(1): 1-11.
Vladimirov VP, Chugunov EM. 2018. The effect of mineral fertilizers and seeding rates on the productivity and oil content of seeds of sunflower in the conditions of forest-steppe of the Middle Volga region. Bull Kazan State Agr Univ 4(51): 16-20.

Vorobiev SA, ed. 1972. Farming, 2nd ed. Moscow.

Wahba SA, Abdel Rahman SI, Tayel MY, Matyn MA. 1990. Soil moisture, salinity, water use efficiency and sunflower growth as influenced by irrigation, bitumen mulch and plant density. Soil Technol 3(1): 33-44.

Zarea MJ, Ghalavand A, Daneshian J. 2005. Effect of planting patterns of sunflower on yield and extinction coefficient. Agron Sustain Develop, Springer Verlag/EDP Sciences/INRA 25(4): 513-518.

Cite this article as: Bushnev AS, Demurin YN, Orekhov GI. 2021. Productivity of sunflower hybrids with erectoid leaves at various plant densities. OCL 28: 39 . 